\title{
Developing of Teaching Materials for Statistics Method Using Hybrid Learning in Industry Challenges 4.0
}

\author{
Sowanto $^{1}$, A Dimyati ${ }^{2}$, Andang $^{3}$, and Mutmainnah ${ }^{4}$ \\ \{sowantos@gmail.com ${ }^{1}$ \} \\ Department of Mathematics Education, STKIP Bima, Jl. Piere Tendean, Bima, Indonesia $a^{1,3,4}$ \\ Department of Mathematics Education, Fakultas Ilmu Tarbiyah \& Keguruan (FITK) UIN Syarif \\ hidayatullah, Jakarta ${ }^{2}$
}

\begin{abstract}
This research is based on the absence of teaching materials on statistical methods oriented to the Indonesian National Qualification Framework (INQF) in the era of the industrial revolution 4.0 which can facilitate students majoring in mathematics education at STKIP Bima with a hybrid learning model that combines face-to-face learning in the classroom and e-learning. The purpose of this study is to produce products in the form of teaching materials that design at online class that is adjusted to hybrid learning oriented to INQF. The method used is design research which includes: (1) preliminary design, in this phase is made Hypothetical Learning Trajectory (HLT); (2) experiments, in this phase existing designs are tested to students; (3) retrospective analysis, in this phase the researchers compare the HLT with the actual student learning process. The results of this research showed that tasks which were presented in teaching materials that combine faceto-face learning in the classroom and e-learning in the form of online classes by considering learning obstacle and preliminary study able to facilitate students to understand the preliminary statistics material, data presentation, and measure of central tendency.
\end{abstract}

Keywords: Teaching Materials, Statistics Method, Hybrid Learning, Industry Challenges 4.0

\section{Introduction}

Mathematics is a part of science that cannot be separated from technological developments. The rapid development of technology which is currently in the era of the industrial revolution 4.0 is a challenge for lecturers as educators to be able to develop learning with a new orientation. [1] revealed that for graduates to be competitive, the curriculum needs a new orientation, because there is an industrial revolution 4.0, it is not enough just to use old literacy (reading, writing, and mathematics) as a basis for working in society but need new literacy (data, technology, human). Therefore, the presence of the Indonesian National Qualification Framework (INQF) through Presidential Regulation Number 8 of 2012 as well as the National Higher Education Standards through The Regulation of Ministry of the Research Technology and Higher Education Number 44 of 2015 allows lecturers as educators to develop learningoriented towards students not to lecturers or subjects.

In the National Higher Education Standards, lecturers, students, and learning resources are an interrelated entity. As one source of knowledge, the role of lecturers in designing interesting learning, in accordance with the times, and easily accepted by students is one of the keys in the learning process. The success of learning activities depends on the ability of the lecturers' 
creativity as educators to create a learning process such that it can stimulate students to learn actively [2].

The lecturer in learning mathematics is required that able to innovate and to create learning devices that are able to develop student's abilities. In order to prepare students, especially competitive mathematics students so they are able to take part in society, one of the innovations that can be done by lecturers as revealed by [3], to develop learning which is a combination of learning through face-to-face in class and online learning, known as hybrid learning.

Through hybrid learning, students are required to learn independently and continuously so that learning will become more effective, efficient, and interesting. This is accorded that revealed too by [4], through hybrid learning-based learning, students are expected to be able to learn independently, sustainably, and develop throughout life so that learning will be more effective, more efficient, and more interesting. This reinforces the need to develop instructional materials in statistical methods with hybrid learning in the era of industrial challenge revolution 4.0 as an innovative step because it was first developed in the STKIP Bima mathematics education study program, the results of which are expected to have an impact on the development of teaching materials in other subjects. Furthermore, [5] explained that by using hybrid learning students have the opportunity to interact with lecturers, students with students and this interaction significantly influence learning outcomes. [6] said that in the process of interaction with the environment, one's performance depends on the interaction between behavior, personal factors, and environmental conditions.

\section{Methods}

The research method used in this research is design research that was developed with hybrid learning in the industrial challenge revolution 4.0. According to Cobb et al [7] design research consists of three phases, namely preliminary design, experimentation, and retrospective analysis which form cyclic processes both in each phase and in the overall design research process. Explanation of the three phases that are adapted to this study are:

\subsection{Preliminary First Design}

At this stage, researchers conducted a theoretical study of the development of teaching materials, hybrid learning, and analyzed several journals that related to statistical methods with the aim of being able to understand the problem more thoroughly and be able to formulate research questions. Furthermore, researchers conducted a preliminary study of the ability of students who had received statistical methods lectures, in this case the participants involved were the fifth-semester students of Mathematics Education Study Program STKIP Bima, as well as making hypotheses of the learning trajectory or Hypothetical Learning Trajectory (HLT) which contained anticipatory matters things that might happen include the student's thought process in the lecture process with hybrid learning in the form of face-to-face learning design in class and online class learning.

\subsection{Experiment}

In this phase, the researcher conducts a preliminary teaching experiment (pilot experiment) of teaching materials that have been designed in semester III students of statistical methods. The 
teaching experiment aims to investigate the learning process related to the process of developing students' way of thinking in situations and learning situations that are formed from HLT so that there will be a match between things that have been anticipated in the initial design phase with the reality that occurs.

\subsection{Retrospective Analysis}

In the retrospective analysis phase, researchers compare HLT from hybrid learning that has been prepared with the actual student learning process, then conduct an analysis of some possible causes and synthesize the possibilities that can be done to improve the HLT that will be used in the next cycle (initial design, experimentation, and analysis next review). After obtaining good teaching materials through three phases, the results are used as material to compile teaching materials in learning with the next hybrid learning.

The subjects of this research were students of mathematics education study program of STKIP Bima in semester V numbering 24 people and students in semester III numbering 18 people in the academic year 2019/2020. The fifth-semester students are involved as participants to explore preliminary data about learning difficulties or learning obstacles in students who have received statistics methods when they are in semester III. While the third-semester students are involved as participants who are used as a testing ground for hybrid learning materials that have been developed.

The selection of undergraduate students in the mathematics education study program of STKIP Bima a participant in research besides consideration is a home base of researchers also has not been conducted in-depth research and study of the difficulties experienced by students as well as teaching materials used by lecturers in statistical methods. In addition, students of STKIP Bima's third-semester mathematics education study program are viewed in terms of facilities and ability to access online media that are already very well supported by their android mobile phones as well as supporting facilities from the campus in the form of free wifi that students can use to support their learning process

Data collection techniques used in this study were observation and interviews. Observation is a non-test evaluation technique that inventory data about students' attitudes and personalities in their learning activities [8]. Observation aims to find out the assignments in teaching materials that are difficult for students to complete and require intervention (assistance) in their completion.

The interview is a conversation with a specific purpose conducted by two parties [9]. Interviews were conducted with the aim of digging deeper information from respondents because it was seen the results of answers to questions could not represent the difficulties of students, through interviews researchers could: (1) identify student difficulties in solving statistical problem courses; (2) knowing students' responses to teaching materials developed by lecturers, so that the benefits of learning with hybrid learning will be known.

Teaching materials that have been completed by students, then an analysis of their answers is done as data. The technique used to analyze the data is based on [10], in the form of activities in qualitative data analysis that take place continuously until completely and interactively carried out. There are three activities in data analysis, namely data reduction, data display, and conclusion drawing/verification. Data reduction means summarizing, choosing the main points, focusing on important things, looking for themes and patterns, and removing unnecessary. After that, through the activity of presenting data, the data will be organized and arranged in a relationship pattern so that it is more easily understood. In qualitative research, the presentation of data is in the form of narrative texts. The last activity is to draw conclusions based on data 
that has been obtained to answer the problem formulation. The determination of this technique considers its compatibility with the research design that has been designed so that its implementation can be carried out systematically.

\section{Results and Discussion}

Design research is a research that develops teaching materials by placing the design process (design) as a strategy. In practice, this study was conducted in three main phases. The three phases are preliminary design, experiment and retrospective analysis.

\subsection{Preliminary First Design}

In this phase, usually a study that begins with the emergence of a problem. The problem examined in this study is the absence of teaching material in statistical methods in accordance with the challenges of the industrial revolution 4.0 that can facilitate students of mathematics education study programs STKIP Bima using hybrid learning. Follow-up from the results of this study, conducted interviews with students and lecturers, analyzed learning difficulties, and made a Hypothetical Learning Trajectory (HLT).

\subsection{Analysis of Student Difficulties}

Learning obstacle faced by students in studying statistical methods courses when adapted to the demands of INQF in the industrial era 4.0. Based on the interview results it was found that there has never been teaching materials or learning methods designed by lecturers that can facilitate the lecturing process of students so that they are able to develop their ability to adjust their abilities according to the development and demands of the times. One of the things that can be done is to familiarize students with learning by combining face-to-face lectures in the classroom with lectures conducted online. The implication of this design is expected to have an impact on the habits of students independently to find learning resources not only have to be directly obtained through lecturers face to face in class, but can also be obtained by online lectures that allow students not only in class.

\subsection{Hypothetical Learning Trajectory (HLT)}

Hypothetical Learning Trajectory (HLT) was arranged as a follow-up from the results of the obstacle learning analysis that was found with the aim of a series of learning plans based on anticipation of possible thought patterns, obstacles, and challenges that students find in learning. Furthermore, based on HLT that has been compiled lecturers develop learning objectives, bring material based on their understanding and knowledge about how students can understand concepts, make estimates about students' initial knowledge, and make assignments that are able to make students to have the desire to understand concepts.

According to Simon and Bakker [7], HLT consists of three components, namely learning objectives, learning activities, and learning hypotheses that will occur. Based on the results of interviews with students and interviews with lecturers of statistical methods, HLT was prepared. The following is an explanation of the hypotheses of student learning trajectories in the learning activities of introductory statistics. 
Learning activity plans that can be prepared in this learning process by paying attention to learning obstacles and studying theories relating to learning. In practice, this research was designed in three meetings with implementation time for each online class that designed can only be accessed in one week. At the first meeting the lecturer explained the rules in the implementation of online classes where for each section ranging from general information to the task to be done must be paid attention to the rules and time limits that have been determined by the lecturer, both the start time worked and the final time limit of the part requested to be completed. The menu display and items provided to be accessed by students at each meeting are designed to consist of material modules, video clips, online discussion forums, online quizzes, and online assignments.

The assignments given in the online class design are as Figure 1 shown below that will be started after students are login at https://bindoelearning.com/login/index.php.

\section{Masuk}

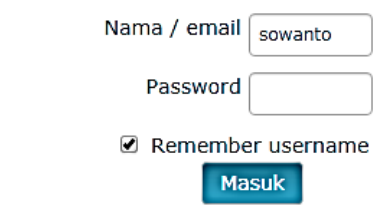

Lupa nama pengguna dan password Anda?

Cookie harus diaktifkan pada browser Anda (?)

Fig 1. Display to login

In accordance with the picture above, students are required to be able to log on to the online lecture site that was previously given by the lecturer. After a successful login, the next display is general information about the online class. The main appearance of the classroom design with online lectures is as shown on Figure 2. 


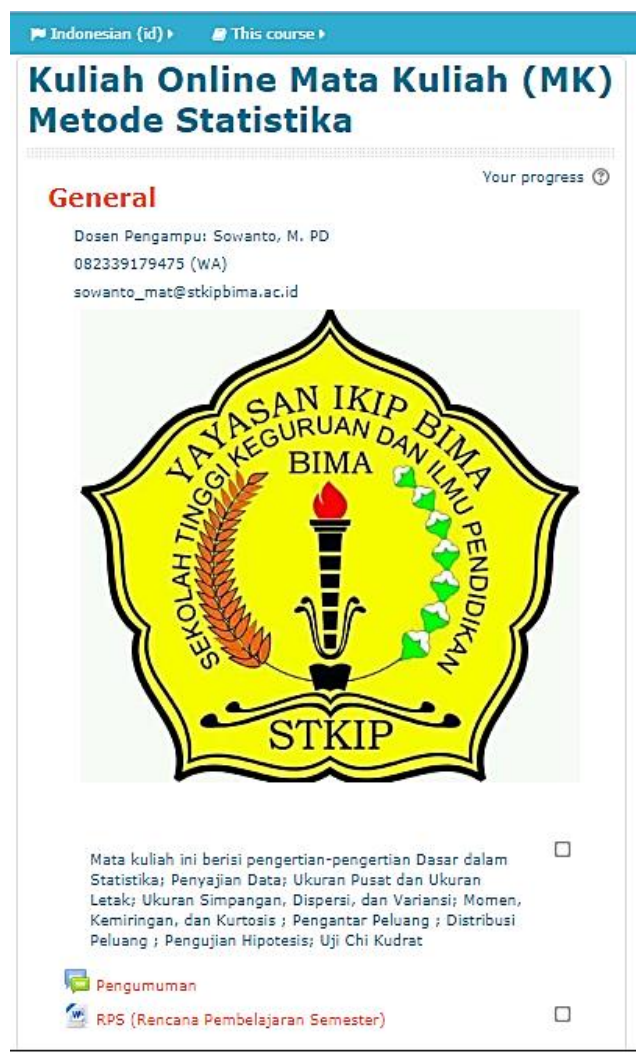

(a)

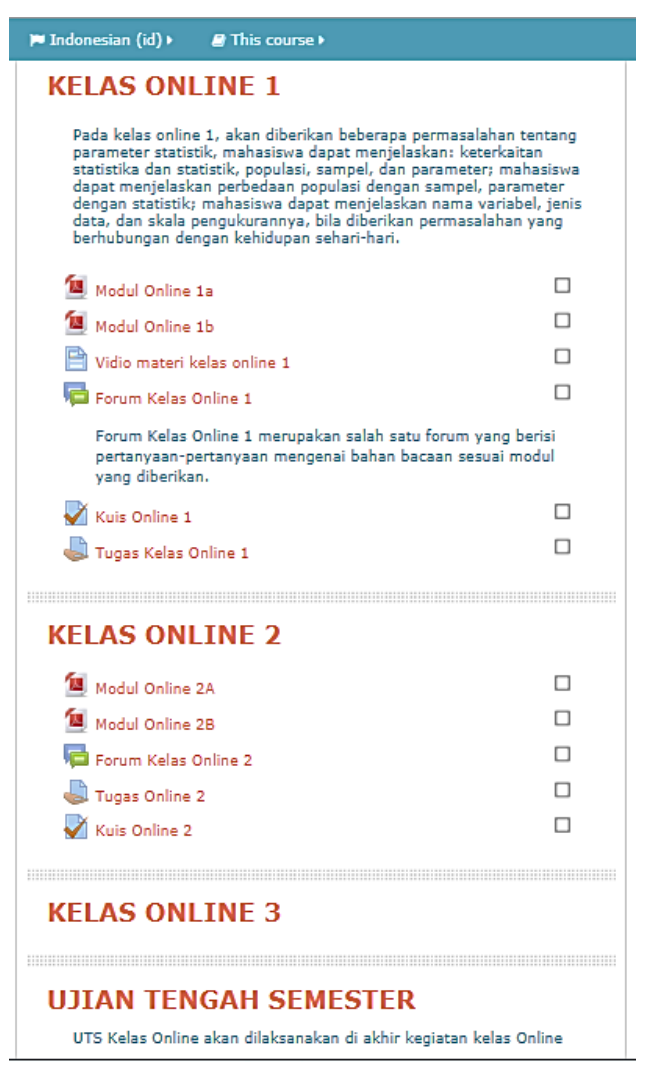

(b)

Fig 2. The main view of the online classes

\subsection{Experiment}

After making the preparation of teaching materials on statistics preliminary materials designed through face-to-face classes and online classes, the next step is to test them on the 3rd semester students of STKIP Bima mathematics education study programs.

\subsection{Retrospective Analysis}

Analysis of the review of learning activities with online lectures is a series starting from the beginning of the lecture activities on the online class until the end of the activities with online classes. Online class learning is carried out with a plan for each online class to take effect in one week. Learning with online classes begins with preliminary information about lectures containing lecturer data, course descriptions, and Semester Learning Plans used in one semester.

At the core of the online classroom activity is inserted a module that contains reading material about the material provided where for the first meeting contains material about 
introductory statistics. In addition to the module, in the beginning the lecturer also designed the students to be able to access the material through links that have been provided containing videos about the material with the aim of increasing students' understanding of the material being studied. The next menu is an online forum that contains open-ended questions that students must respond with answers. This forum is created in the middle of an effective online class, so that lecturers can check the level of activeness, understanding, and response of students regarding the material provided.

In the quiz section given with a predetermined duration and the time for the implementation, the students seemed to have been able to answer the questions correctly even though there were still students who delivered late because they forgot to read the quiz time. The thing done by the lecturer is by giving a warning on the quiz menu and reminding the head of the level to be able to remind his friends via whatsapp group. As for online assignments, students are required to be able to make in the form of word files where as a whole students are able to do the assignments by re-uploading with their respective accounts in the online class that the lecturer has designed.

Based on the description of the results of student activities in online classes that have been designed, it can be concluded that online classes provided for statistics methods can facilitate students to understand the preliminary statistics material, tables and graphics, as well as central tendency material. Although in the process of implementing interactions with online classes there are still students who still don't understand what needs to be done for the online class stages. This can be overcome by the lecturer giving instructions on each menu and for time limits to be reminded through the label that also provides interaction through the group whatsapp groups of fellow students.

\section{Conclusion}

Based on the results of research and discussion in this study, it can be concluded that the tasks presented in online class 1 by considering obstacle learning and preliminary studies are able to facilitate students to understand the preliminary statistics material; The assignments presented in online class 2 by considering obstacle learning and preliminary studies are able to facilitate students to give opinions about: data presentation in the form of tables, diagrams, and graphs; The assignments presented in online class 3 by considering obstacle learning and preliminary studies are able to facilitate students to be able to explain the size of the central tendency and the size of the location.

Acknowledgments. The authors would like to thank Kemenristekdikti for the research grant provided

\section{References}

[1]Aoun J E 2017 Higher Education in the Age of Artificial Intelligence. Cambridge: The MIT Press. [2]Slameto 2010 Belajar dan Faktor-Faktor yang Mempengaruhinya. Jakarta: Rineka Cipta.

[3]Shea J, Joaquin M E and Gorzycki M 2015 Hybrid course design: Promoting student engagement and success. Journal of Public Affairs Education 214 539-556 
[4]Prelly M J T 2017 Pengembangan Media Pembelajaran Biologi Berbasis Hybrid Learning untuk Meningkatkan Hasil Belajar Siswa pada SMP Negeri 6 Ambon. Biosel (Biology Science and Education): Jurnal Penelitian Sains dan Pendidikan 62 186-192.

[5]Shea P and Bidjerano T 2010 Learning presence: Towards a theory of self-efficacy, selfregulation, and the development of a communities of inquiry in online and blended learning environments. Computers \& Education 554 1721-1731.

[6]Sowanto and Y S Kusumah 2018 J. Phys.: Conf. Ser. 1013012107

[7]Mulyana D 2012 Metode Penelitian Kualitatif: Paradigma Baru Ilmu Komunikasi dan Ilmu Sosial Lainnya. Bandung: Remaja Rosdakarya.

[8]Suherman E 1990 Petunjuk Praktis untuk Melaksanakan Evaluasi Pendidikan Matematika. Bandung:Wijayakusumah.

[9]Moleong J 2010 Metodologi Penelitian Kualitatif. Bandung: PT Remaja Rosdakarya.

[10]Miles M B and Huberman A M 1984 Qualitative Data Analysis: A Source Book or New Methods. Beverly Hills: Sage Publication 